\title{
Analisa Pengaruh Perubahan Tilt Antena Sektoral BTS Secara Electrical Dan Mechanical Site XL 3G Pakubuwono
}

\author{
Aziz Makkatang, Rianto Nugroho \\ Program Studi Teknik Elektro, Fakultas Teknik dan Sains, Universitas Nasional \\ Korespondensi : riantnugroho@yahoo.com
}

\begin{abstract}
ABSTRAK. Pada dasarnya unjuk kerja atau performansi sistem seluler baik berbasis sistem CDMA maupun GSM dapat diukur dengan melihat beberapa parameter Quality of Service (QoS) jaringan, Masing - masing operator mempunyai standart sendiri didalam unjuk kerja jaringannya, atau yang biasa disebut dengan Key Performance Indicator (KPI). Dalam analisa ini Disini kita dapat mengetahui penurunan layanan jaringan GSM, maka dilakukan survey lapangan dan menerima keluhan dari pelanggan. Dari keluhan pelanggan tersebut kemudian dilakukan drive test. Drive test adalah salah satu langkah awal dalam proses optimasi jaringan yang bertujuan untuk mengumpulkan data-data pengukuran pada suatu area kurang optimal. Dari hasil penelitian salah satu penyebab menurunnya level sinyal dan kualitas sinyal pada suatu area adalah rundukan (tilting) maka dilakukan pengukuran dimana Tilting memberikan pengaruh yang sinifikan terhadap cakupan dari suatu BTS. Dari hasil yang di peroleh Tilting secara electrical $2^{\circ}$ didapatkan hasil sebesar $76 \mathrm{dBm}$, sedangkan Tilting secara Mechanical $2^{\circ}$ didapatkan hasil sebesar $-90 \mathrm{dBm}$, tilting secara electrical memberikan perolehan sinyal yang lebih baik di bandingkan tilting secara mechanical. Pada tilting secara electrical didapatkan rata-rata perolehan sinyal yang lebih baik daripada mechanical tilting.
\end{abstract}

Kata kunci : Drive Test, Quality of Service, Directivity

\begin{abstract}
Basically performance or performance of cellular system based on CDMA and GSM system can be measured by looking at some of Quality of Service (QoS) parameter of network, Each operator has its own standard in its network performance, or commonly called Key Performance Indicator (KPI ). In this analysis Here we can know the decline of GSM network services, then conducted field surveys and received complaints from customers. From customer complaints are then performed drive test. Drive test is one of the first steps in the process of network optimization that aims to collect measurement data in an area less than optimal. From the research result of one of the causes of decreasing signal level and signal quality in an area is tilting, then measurement where Tilting gives a significant influence to the coverage of a BTS. From the results obtained Tilting the electrical $2^{\circ}$ obtained results of $-76 \mathrm{dBm}$, whereas Mechanical Tilting $2^{\circ}$ obtained the results of $-90 \mathrm{dBm}$, tilting the electrical provides better signal acquisition in tilting by mechanical. In tilting the electrical obtained a better average signal gain than mechanical tilting.
\end{abstract}

Keywords : Drive Test, Quality of Service, Directivity

\section{PENDAHULUAN}

Performansi sistem seluler baik berbasis sistem CDMA maupun GSM dapat diukur dengan melihat beberapa parameter Quality of Service (QoS) jaringan. Operator seluler di negara maju melakukan pengujian unjuk kerja jaringannya secara periodic agar kinerja system dapat dipertahankan. Untuk menganalisis jaringan sinyal MS tersebut dapat dianalisa dari perubahan Tilt antena sektoral BTS secara electrical dan mechanical. Disini kita dapat mengetahui penurunan layanan jaringan GSM tersebut. Data tersebut dapat dipergunakan untuk mengidentifikasi masalah-masalah jaringan seperti level sinyal (RxLev) yang lemah, kualitas sinyal (Rx Qual) yang buruk, dan sebagainya. Salah satu penyebab menurunnya level sinyal dan kualitas sinyal pada suatu area adalah rundukan (tilting). Pengoptimalisasian jaringan dilakukan dengan bantuan peralatan drive test sistem konvensional yang terdiri dari sebuah handset MS (mobile station) tipe Soni Ericsson T68, softwere TEMS Investigation Version 4.1 untuk 
mengontrol dan menyimpan data dari test mobile tersebut, dan sebuah penerima Global Positioning System ( GPS ) untuk informasi posisi.

\section{LANDASAN TEORI}

\section{Direktivitas Antena}

Directivity dari sebuah antena atau deretan antena diukur pada kemampuan yang dimiliki antena untuk memusatkan energi dalam satu atau lebih ke arah khusus. Antena dapat juga ditentukan pengarahanya tergantung dari pola radiasinya. Dalam sebuah array propagasi akan diberikan jumlah energi, gelombang radiasi akan dibawa ketempat dalam suatu arah. Elemen dalam array dapat diatur sehingga akan mengakibatkan perubahan pola atau distribusi energi lebih yang memungkinkan ke semua arah (omnidirectional). Suatu hal yang tidak sesuai juga memungkinkan. Elemen dapat diatur sehingga radiasi energi dapat dipusatkan dalam satu arah (unidirectional). Direktivitas antena merupakan perbandingan kerapatan daya maksimum dengan kerapatan daya rata-rata. Maka dapat dituliskan pada persamaan :

$$
\text { Direktivitas }=\mathbf{D}=\frac{P(\theta, \emptyset) r}{P(\theta, \emptyset) \text { rat }}
$$

\section{Gain Antena}

Gain (directive gain) adalah karakter antena yang terkait dengan kemampuan antena mengarahkan radiasi sinyalnya, atau penerimaan sinyal dari arah tertentu. Gain bukanlah kuantitas yang dapat diukur dalam satuan fisis pada umumnya seperti watt, ohm, atau lainnya, melainkan suatu bentuk perbandingan. Oleh karena itu, satuan yang digunakan untuk gain adalah desibel.

Gain dapat dihitung dengan membandingkan kerapatan daya maksimum antena yang diukur dengan antena referensi yang diketahui gainnya. Maka dapat dituliskan pada Persamaan:

Dimana :

$$
\text { Gt }(\mathbf{d B})=(\operatorname{Pt}(\mathbf{d B m})-\mathbf{P s}(\mathbf{d B m}))+\mathbf{G s}(\mathrm{dB})
$$

$\begin{array}{lll}\mathrm{Gt} & = & \text { Gain total antena. } \\ \mathrm{Pt} & = & \text { Nilai level sinyal maksimum yang diterima antena terukur }(\mathrm{dBm}) . \\ \mathrm{Ps} & = & \text { Nilai level sinyal maksimum yang diterima antena referensi }(\mathrm{dBm}) \\ \mathrm{Gs} & = & \text { Gain antena referensi. }\end{array}$

\section{Pola Radiasi Antena}

Pola radiasi antena atau pola antena didefinisikan sebagai fungsi matematik atau representasi grafik dari sifat radiasi antena sebagai fungsi dari koordinat. Di sebagian besar kasus, pola radiasi ditentukan di luasan wilayah dan direpresentasikan sebagai fungsi dari koordinat directional. Pola radiasi antena adalah plot 3-dimensi distribusi sinyal yang dipancarkan oleh sebuah antena, atau plot 3-dimensi tingkat penerimaan sinyal yang diterima oleh sebuah antena. Pola radiasi antena menjelaskan bagaimana antena meradiasikan energi ke ruang bebas atau bagaimana antena menerima energi. Antena omnidirectional mempunyai pola radiasi yang digambarkan seperti bentuk kue donat (doughnut) dengan pusat berimpit. Antena Omnidirectional pada umumnya mempunyai pola radiasi $360^{\circ}$ jika dilihat pada bidang medan magnetnya. Polarisasi antena merupakan orientasi perambatan radiasi gelombang elektromagnetik yang dipancarkan oleh suatu antena dimana arah elemen antenna terhadap permukaan bumi sebagai referensi lain. Energi yang berasal dari antena yang dipancarkan dalam bentuk sphere, dimana bagian kecil dari sphere disebut dengan wave front. Pada umumnya semua titik pada gelombang depan sama dengan jarak antara antena. Selanjutnya dari antena tersebut, gelombang akan membentuk kurva yang kecil atau mendekati. Dengan mempertimbangkan jarak, right angle ke arah dimana gelombang tersebut dipancarkan. Pemakaian sebuah antena dalam sistem pemancar atau penerima selalu dibatasi oleh daerah frekuensi kerjanya. Pada range frekuensi kerja tersebut antena dituntut harus dapat bekerja dengan efektif agar dapat menerima atau memancarkan gelombang pada band frekuensi 
tertentu. Bandwidth yang dinyatakan dalam persen seperti ini biasanya digunakan untuk menyatakan bandwidth antena yang memiliki band sempit (narrow band). Sedangkan untuk band yang lebar (broad band) biasanya digunakan definisi rasio antara batas frekuensi atas dengan frekuensi bawah.

\section{Antena Sektoral}

Antenna sektoral umumnya mempunyai penguatan lebih tinggi dari antenna omni sekitar 10-19 dBi. Sangat baik untuk memberikan servis di daerah dalam jarak 6-8 km. Tingginya penguatan pada antenna sektoral biasanya di kompensasi dengan lebar pola radiasi yang sempit 45-180 derajat. Jelas daerah yang dapat di servis menjadi lebih sempit, dan ini sangat menguntungkan. Secara umum radiasi antenna lebih banyak ke muka antenna, tidak banyak radiasi di belakang antenna sektoral. Radiasi potongan vertikal tidak berbeda jauh dengan antenna omni. Antena sektoral seperti halnya Antena Omnidirectional mempunyai polarisasi vertikal \& dirancang untuk digunakan pada base stasion (BTS) tempat Akses Point berada. Berbeda dengan antena omnidirectional yang dapat memberikan servis dalam jangkauan 360 derajat. Antena sektoral hanya memberikan servis pada wilayah/sektor yang terbatas. Biasanya 45-180 derajat saja. Pengaturan pancaran antena BTS menjadi sektoral (bukan omnidirectional) dilakukan dengan beberapa alasan teknis, diantaranya adalah meningkatkan kapasitas jaringan. Sudut sektor yang umum biasanya di operasionalkan biasanya 120 derajat, sementara sudut sektor 90 derajat juga di terapkan di beberapa BTS. Keuntungan yang diperoleh dengan membatasi wilayah servis tersebut, antena sektoral mempunyai gain yang lebih besar daripada antenna omnidirectional. Biasanya antena sektoral mempunyai gain antara 10-19 dBi.

\section{Sistem komunikasi selular}

Sistem komunikasi seluler merupakan salah satu jenis komunikasi bergerak, yaitu suatu komunikasi antara dua buah terminal dengan salah satu atau kedua terminal berpindah tempat. Dengan adanya perpindahan tempat ini, sistem komunikasi bergerak tidak menggunakan kabel sebagai medium transmisi. Pada GSM (Global System for Mobile communication) adalah suatu teknologi yang digunakan dalam komunikasi mobile dengan teknik digital. Sebagai teknologi yang dapat dikatakan cukup revolusioner karena berhasil menggeser teknologi sistem telekomunikasi bergerak analog yang populer pada dekade 80-an, GSM telah memberikan alernatif berkomunikasi baru bagi dunia telekomunikasi yang lebih powerful. Dengan menggunakan sistem sinyal digital dalam transmisi datanya, membuat kualitas data maupun bit rate yang dihasilkan menjadi lebih baik dibanding sistem analog. GSM 900 menggunakan frekuensi $900 \mathrm{MHz}$ sebagai kanal transmisinya. GSM 1800 dan 1900 masing-masing menggunakan frekuensi 1800 dan $1900 \mathrm{MHz}$.

\section{Konsep Dasar Jaringan WCDMA-UMTS}

WCDMA merupakan teknologi generasi ketiga (3G) yang berbasis packet service dengan menggunakan standar Direct Sequence Spread Spectrum dan modulasi RF yang digunakan adalah QPSK saat uplink maupun downlink. Standar bandwidth yang dipakai sebesar $5 \mathrm{Mhz}$ yang dapat ditingkatkan sampai dengan $10 \mathrm{Mhz}, 15 \mathrm{Mhz}$, dan $20 \mathrm{Mhz}$. Sedangkan dukungan mobilitas yang dapat dilayani

sampai dengan $120 \mathrm{~km} / \mathrm{jam}$. Beberapa hal yang dimiliki oleh teknologi WCDMA ini adalah :

- Mendukung pengiriman data dengan kecepatan tinggi (> 384 kbps pada lingkup area yang lebar dan dapat mencapai $2 \mathrm{Mbps}$ pada daerah indoor/local outdoor coverage),

- Sistem layanan yang fleksibel yang mendukung multiple parallel variable rate services pada tiap-tiap koneksi,

- Dukungan terhadap handover antar frekuensi untuk pengoperasian dengan struktur sel yang bertingkat,

- Implementasi yang mudah pada terminal dual mode UMTS/GSM baik itu handover diantara UMTS dan GSM,

- Kerahasiaan yang tinggi,

- Dapat diaplikasikan pada lingkungan interferensi yang tinggi,

- Menyediakan kapasitas yang lebih besar daripada sistem FDMA, TDMA, maupun NarrowBand CDMA. 
Sel (cell) merupakan unit geografi terkecil dalam jaringan seluler. Ukuran sel yang berbedabeda dipengaruhi oleh keadaan geografis dan besar trafik yang akan di layani. Sel yang memiliki kepadatan trafik tinggi ukuran sel dibuat kecil dan sel yang memiliki kepadatan trafik rendah ukuran sel dibuat lebih besar. Selain istilah sel, pada sistem seluler dikenal pula istilah cluster yaitu kumpulan dari sel. Pada sistem seluler semua daerah dapat dicakup tanpa adanya gap sel satu dengan yang lain sehingga bentuk sel secara heksagonal lebih mewakili di banding bentuk lingkaran. Bentuk lingkaran lebih mewakili perserbaran daya yang ditransmisikan oleh antena. Bentuk seperti itu adalah bentuk ideal, didalam prakteknya bentuk seperti itu tidak pernah di temukan, karena radiasi antena tidak bisa membentuk daerah cakupan seperti itu, disamping itu keadaan geografis (kontur) turut mempengaruhi bentuk sel.

\section{PERENCANAAN TILTING ANTENA SEKTORAL DAN TEMS INVESTIGATION}

\section{Tilting Antena}

Tilting antena adalah suatu pengaturan kemiringan antena yang berfungsi untuk menetapkan area yang akan menerima cakupan sinyal. Untuk mengubah coverage area yang dilayani oleh BTS dapat dilakukan dengan teknik tilting, yaitu pemiringan/perubahan antena yang dilakukan untuk mengatur coverage dari antenna.

\section{Tilting Electrical}

Pada electrical tilting tidak adanya perubahan secara sisi fisik antena. Kemiringan dilakukan dengan menggeser fasa dari antena, semakin dilakukan kemiringan, backlobe akan semakin mengalami penurunan ke bawah sehingga penggunaan electrical tilt tanpa melakukan mechanical tilt adalah pilihan yang menarik untuk alasan estetika yang sangat penting bagi operator mencari penerimaan antena terintegrasi di lokasi terlihat.

\section{Drive Test dengan TEMS Investigation 8}

Sebelum melakukan drive test ada baiknya mempersiapkan terlebih dahulu peralatan yang akan digunakan seperti laptop (yang telah terinstal TEMS), hanphone, GPS, dan scanner. Kemudian melakukan persiapan maping yang meliputi rute dan posisi site yang akan diuji. Langkahlangkah drive test meliputi: koneksi tools, parameter pengamatan, drive test, logfile preview dan reporting.

\section{Parameter Pengamatan}

Sebelum melakukan recording, blok parameter yang akan diamati terlebih dahulu di siapkan. Pada pengujian jaringan $3 \mathrm{G}$ maka parameter yang akan diamati meliputi perolehan sinyal, S/N, throughput data transfer dan command sequence untuk mempermudah pengamatan layanan sehingga instruksi sequence dapat dijalankan secara otomatis. Blok map harus ada untuk mengetahui posisi dan pergerakan yang dilakukan kemudian blok even untuk mengamati even list yang terjadi.

\section{Drive Test}

Istilah drive test juga sudah umum digunakan untuk pengetesan dengan berjalan kaki (walk test) yang umumnya dilakukan pada pengetesan koneksi jaringan pada gedung-gedung bertingkat. Drive test adalah hal yang fundamental dalam optimasi jaringan telekomunikasi. Karena dengan drive test, seorang engineer dapat menentukan keunggulan jaringan yang dibangun serta meningkatkan performa jaringan.

\section{Reporting}

Setelah mengamati hasil drive test yang dilakukan maka langkah selanjutnya adalah reporting, yaitu mengambil data-data yang dibutuhkan untuk menentukan kualitas jaringan yang diuji. Map info adalah software bantu yang juga dikeluarkan oleh perusahaan Ericcson yang sering berada dalam paket software TEMS sendiri bersama MCOM. Dimana Mapinfo dan MCOM digunakan untuk maping. 


\section{ANALISA \& PENGUJIAN TILTING ANTENA}

\section{Persiapan Pengujian dan Pengamatan}

Persiapan pengujian dan pengamatan meliputi persiapan peralatan dan software pendukung. Adapun peralatan tilting dipersiapkan oleh rigger. Rigger adalah pemanjat tower yang bertugas merubah parameter dan posisi antena BTS. Peralatan tersebut meliputi, Tilt Meter, Kompas, Kamera, Saftybelt, Body Harnes, Kunci 13, 14 dan kunci bunga. Software yang digunakan untuk pengamatan menggunakan software Tems Investigation 8.1. Pengujian dilakukan pada satu antena sektoral saja yaitu antena sektoral 2 dengan directional pada arah $150^{\circ}$ dengan pengarahan pada neighbour site $3 G$ PATIUNUS Sector 3.

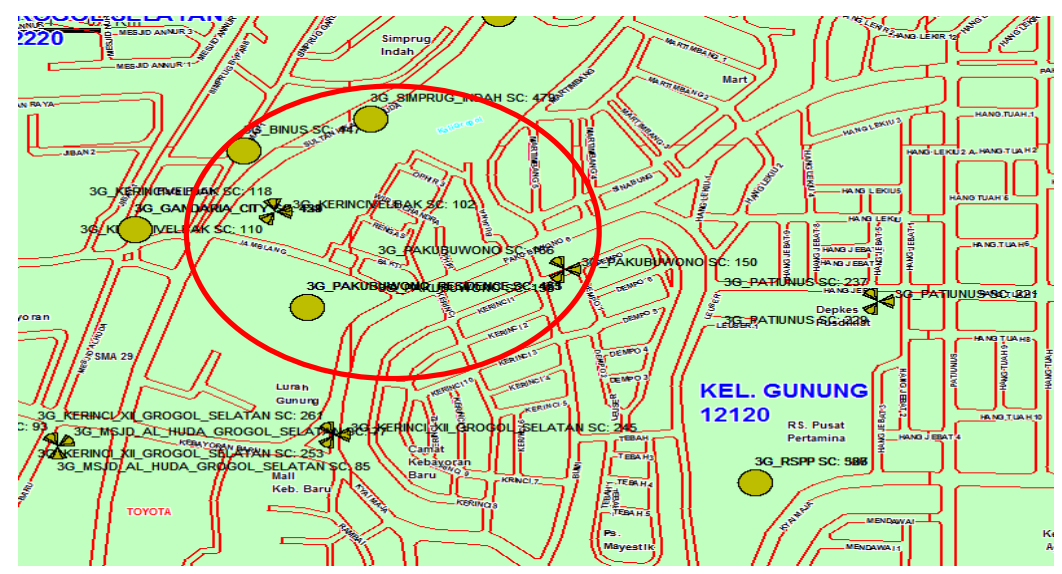

GAMBAR 1. Map menunjukkan posisi site yang akan diuji.

\section{Perhitungan Tilting}

Tipe antena yang digunakan adalah Katherine 741987 dengan vertical beam $6.2^{\circ}$ dan beamwidth $120^{\circ}$. Jarak BTS uji dengan BTS neighbour $0,5 \mathrm{~km}$. Tinggi antena dari tanah 20 meter. Gambar dibawah menunjukkan pengukuran jarak antar BTS. Dari data yang terlihat pada Tabel diperoleh tilting site neighbour mechanical tilt 0 dan electrical tilt 2.

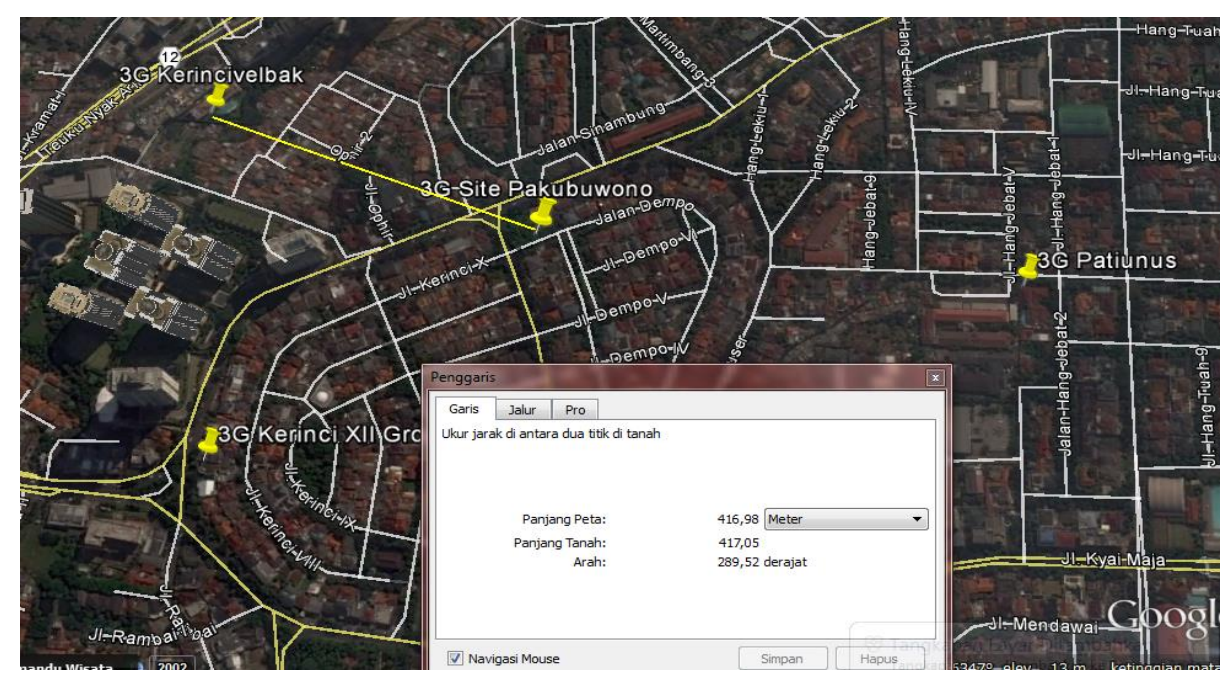

GAMBAR 2. Pengukuran jarak antar BTS

Dapat dihitung tilting yang dibutuhkan untuk memperoleh cakupan yang optimum sebagai berikut :

Beam $\left.<3 \mathrm{~dB}=20 / \operatorname{Tan}\left(2^{\circ}+6.2^{\circ} / 2\right)\right)[$ meter $]$

Main beam $=20 /$ Tan $\left(2^{\circ}\right)$ [meter]

Beam $\left.>3 d B=20 / \operatorname{Tan}\left(2^{\circ}-6.2^{\circ} / 2\right)\right)$ [meter]

Dimana :

Jarak $=$ Beam (meter) 
$\mathrm{Ha}=20$ meter

Downtilt $=2^{\circ}$ (karena pengukuran yang di lakukan dengan memiringkan antena sebesar 20)

Vertikal Beamwith $=6.2^{\circ}$ (vertical beamwitdh berdasarkan spesifikasi antena yang digunakan seperti yang terlihat pada Lampiran 1 yaitu spesifikasi antena Katherine 741987)

Dengan demikian pada downtilt $2^{\circ}$ antena sel ini memiliki beam sebagai berikut :

$$
\begin{array}{ll}
\text { Beam }<3 \mathrm{~dB} & =0.2241 \mathrm{Km} \\
\text { Main beam } & =0.5727 \mathrm{Km} \\
\text { Beam }>3 \mathrm{~dB} & =1.0417 \mathrm{Km}
\end{array}
$$

Sementara pada BTS uji downtilt $0^{\circ}$

Beam $<3 \mathrm{~dB} \quad=$ over horizon $\mathrm{Km}$

Main beam $=$ over horizon $\mathrm{Km}$

Beam $>3 \mathrm{~dB}=0,3693 \mathrm{Km}$

\section{Tilting Secara Electrical dan Mechanical}

Perubahan tilting dilakukan pada electrical tilt dengan tetap membuat posisi mechanical tilting pada angka nol. Dari perhitungan diperoleh tilting yang optimum dilakukan adalah $2^{\circ}$ kemiringan. Perubahan tilting secara electric dilakukan dengan tahapan-tahapan sebagai berikut: baut penyangga batang elemen di kendurkan, penyangga ditahan supaya tidak jatuh, turunkan batang elemen sesuai derajat kemiringan yang diingin dan eratkan kembali baut penyangga. Perubahan tilting dilakukan pada mechanical tilt dengan tetap membuat posisi electrical tilting pada angka nol. Perubahan tilting sebesar $20^{\circ}$. Perubahan tilting dilakukan pada mechanical tilt dan electrical tilt. Perubahan tilting sebesar $1^{\circ}$ pada mechanical dan electrical tilt sehingga mendapatkan kemiringan total yaitu $2^{\circ}$. Gambar dibawah menunjukkan tilting yang dilakukan.

\section{Pengujian Parameter}

Setelah dilakukan perubahan tilting dilakukan pengujian parameter. Parameter yang diuji meliputi kuat sinyal dan Ec/No., titik soft handover dan call setup succes rate (CSSR) voice dan video call. Langkah-langkah yang dilakukan pada pengujian parameter meliputi drive test dengan dua mobile station dimana satu mobile (MS1) mendial voice call dan satu lagi (MS2) menerima. Dilakukan berulang (looping) dengan durasi call 45 detik dan 10 detik jeda sebelum melakukan call selanjutnya. Hal ini dilakukan untuk melihat call setup succes ratio (CSSR); drive test dengan dua mobile station dimana satu mobile mendial video call dan satu lagi menerima. Dilakukan berulang (looping) dengan durasi call 45 detik dan 10 detik jeda sebelum melakukan call selanjutnya. Hal ini dilakukan untuk melihat call succes ratio (CSR). Pengujian kuat sinyal dan Ec/No diambil dari data pembacaan pada satu mobile station ketika melakukan drive test.

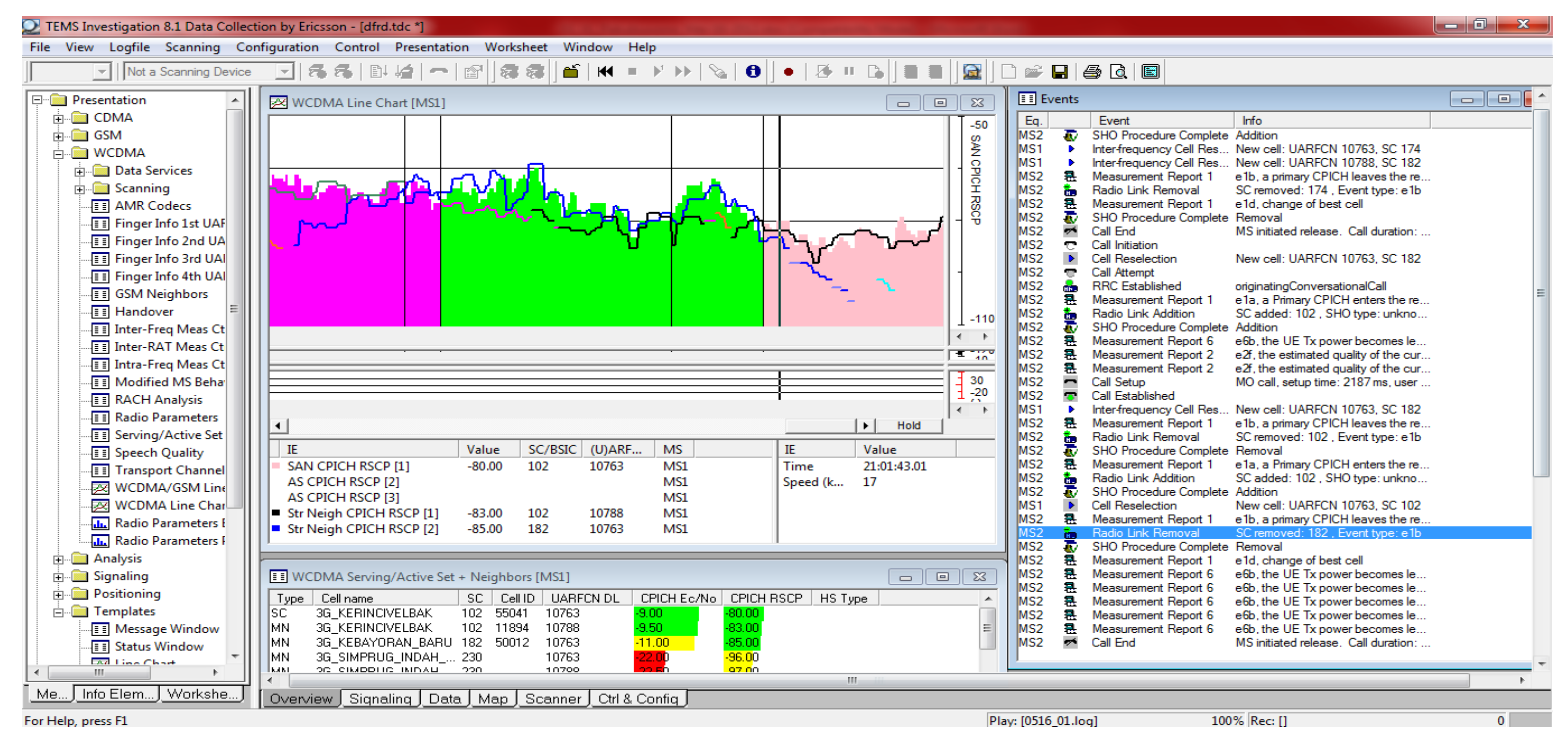

GAMBAR 3. Screen shoot software Tems ketika pengambilan data dilakukan. 
Perolehan kuat sinyal dan Ec/No sebelum dilakukan perubahan tilting (Tilting $0^{\circ}$ ). Perolehan kuat sinyal ditunjukkan sebelum dilakukan perubahan tilting diperlihatkan oleh Gambar 4.9. yang diperoleh dari data terlampir. Dimana pada $\mathrm{x}$ parameter ialah jarak dengan satuan meter dan parameter y adalah besar daya yang terbaca dengan satuan $\mathrm{dBm}$.

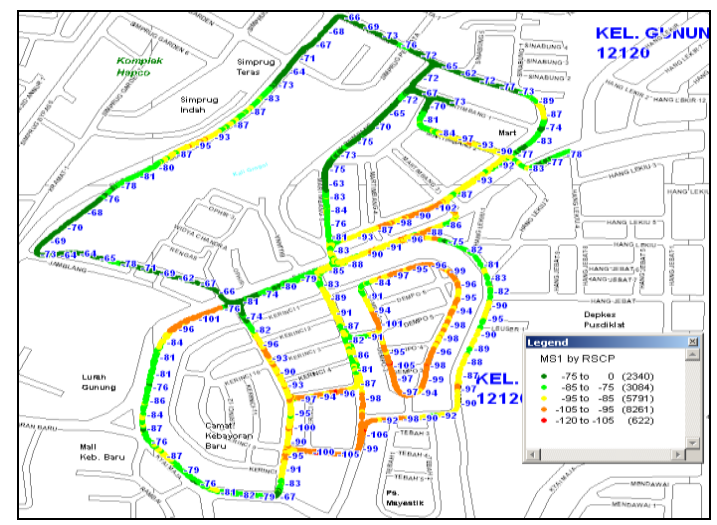

\begin{tabular}{lll}
\hline Range & Count & Persentase (\%) \\
\hline-75 to 0 & 2340 & $11,66 \%$ \\
-85 to -75 & 3048 & $15,19 \%$ \\
-95 to -85 & 5791 & $28,87 \%$ \\
-105 to -95 & 8261 & $41,18 \%$ \\
-120 to -105 & 622 & $3,10 \%$ \\
\hline
\end{tabular}

GAMBAR 4. Perolehan Kuat Sinyal Pada Mobile Station pada Tilting 0

Perolehan Ec/No ditunjukkan sebelum dilakukan perubahan tilting diperlihatkan oleh Gambar dibawah;

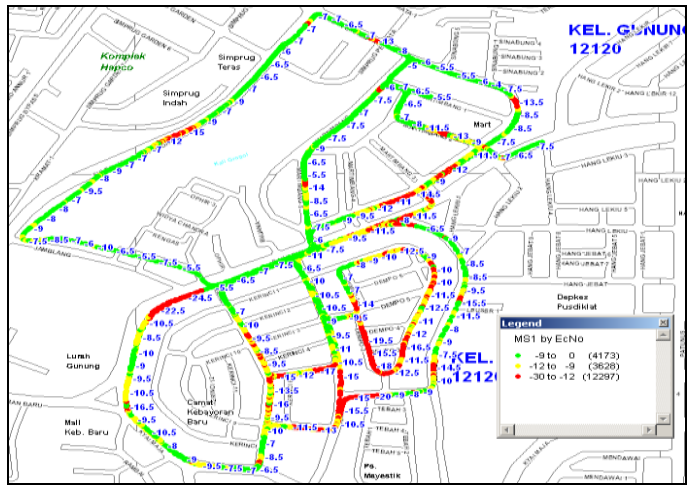

\begin{tabular}{lll}
\hline Range & Count & Persentase $(\%)$ \\
\hline-9 to 0 & 4173 & $20,76 \%$ \\
-12 to -9 & 3628 & $18,05 \%$ \\
-30 to -12 & 12297 & $61,19 \%$ \\
\hline
\end{tabular}

GAMBAR 5. EcNo Pada Mobile Station Pada Tilting 0

Perolehan kuat sinyal dan Ec/No pada Electrical Tilt $2^{\circ}$. Perolehan kuat sinyal pada perubahan electrical tilting pada kemiringan $2^{\circ}$ diperlihatkan oleh Gambar dibawah;

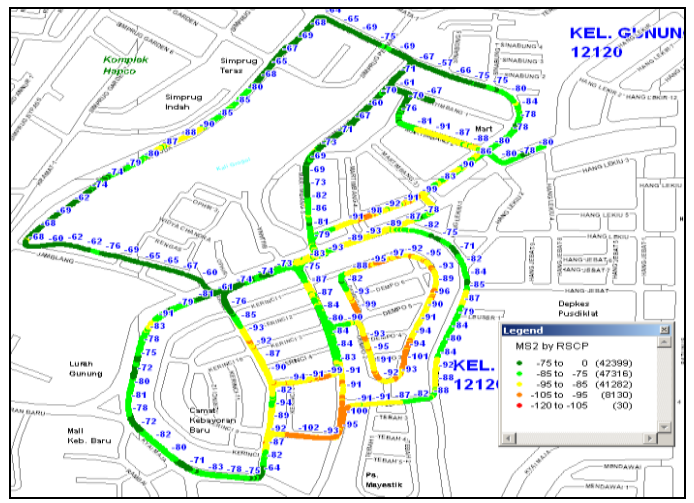

\begin{tabular}{lll}
\hline Range & Count & Persentase (\%) \\
\hline-75 to 0 & 42399 & $30,47 \%$ \\
-85 to -75 & 47316 & $34,00 \%$ \\
-95 to -85 & 41282 & $29,67 \%$ \\
-105 to -95 & 8130 & $5,84 \%$ \\
-120 to -105 & 30 & $0,02 \%$ \\
\hline
\end{tabular}

GAMBAR 6. Perolehan Kuat Sinyal Pada Mobile Station pada Electrical Tilting $2^{\circ}$

Perolehan Ec/No ditunjukkan setelah dilakukan perubahan tilting secara electrical $2^{\circ}$ diperlihatkan oleh Gambar dibawah ; 


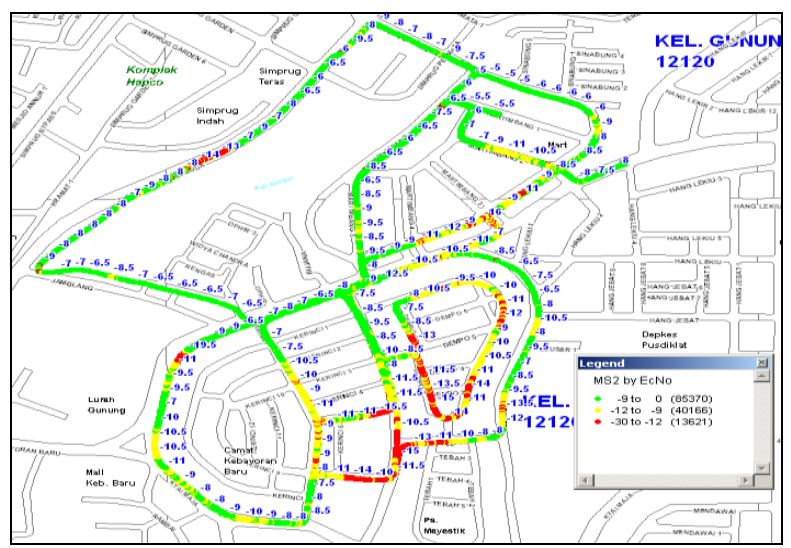

\begin{tabular}{|l|l|l|}
\hline Range & Count & Persentase $(\%)$ \\
\hline-9 to 0 & 85370 & $61,35 \%$ \\
\hline-12 to -9 & 40166 & $28,86 \%$ \\
\hline-30 to 12 & 13621 & $9,79 \%$ \\
\hline
\end{tabular}

GAMBAR 7. EcNo Pada Mobile Station Pada Electrical Tilting $2^{\circ}$

Perolehan kuat sinyal dan Ec/No pada Mechanical Tilt $2^{\circ}$

Perolehan kuat sinyal pada perubahan mechanical tilting pada kemiringan $2^{\circ}$ diperlihatkan oleh Gambar dibawah.

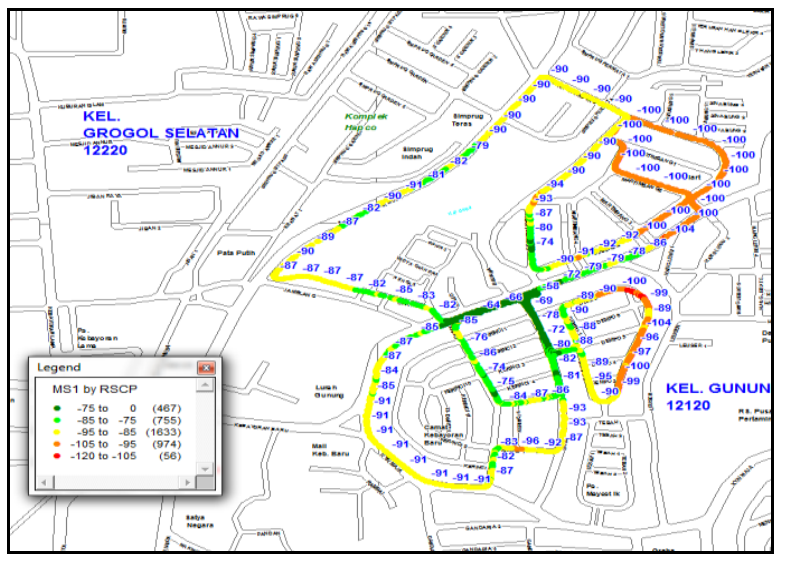

\begin{tabular}{ccc}
\hline Range & Count & Persentase (\%) \\
\hline-75 to 0 & 467 & $12,02 \%$ \\
-85 to -75 & 755 & $19,43 \%$ \\
-95 to -85 & 1633 & $42,03 \%$ \\
-105 to -95 & 974 & $25,07 \%$ \\
-120 to -105 & 56 & $1,44 \%$ \\
\hline
\end{tabular}

GAMBAR 8. Perolehan Kuat Sinyal Pada Mobile Station pada mecanical Tilting $2^{\circ}$

Perolehan Ec/No ditunjukkan setelah dilakukan perubahan tilting mechanical $2^{\circ}$ diperlihatkan oleh Gambar dibawah

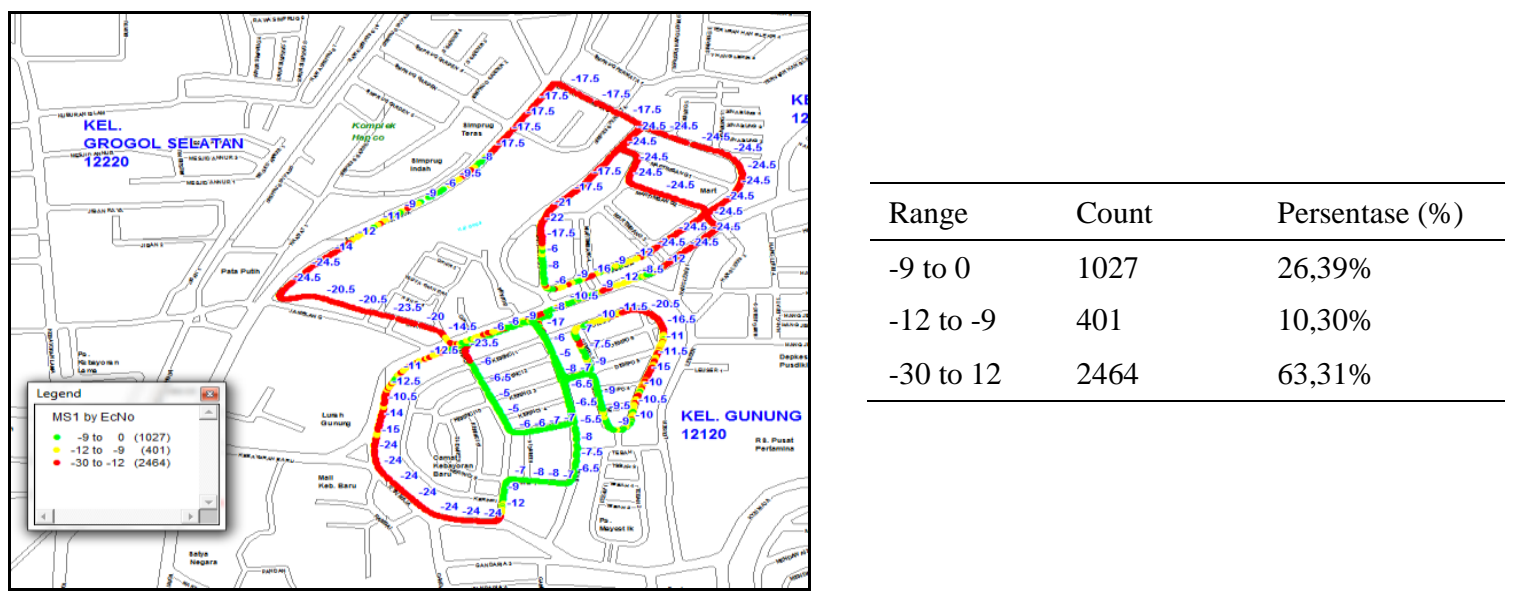

GAMBAR 9. EcNo Pada Mobile Station Pada Mecanical Tilting $2^{\circ}$.

Perolehan kuat sinyal dan Ec/No Tilt $2^{\circ}$ dengan penggabungan electrical dan mecanical tilt Perolehan kuat sinyal pada perubahan Tilt $2^{\circ}$ dengan penggabungan electrical dan mecanical tilt diperlihatkan oleh Gambar dibawah. 


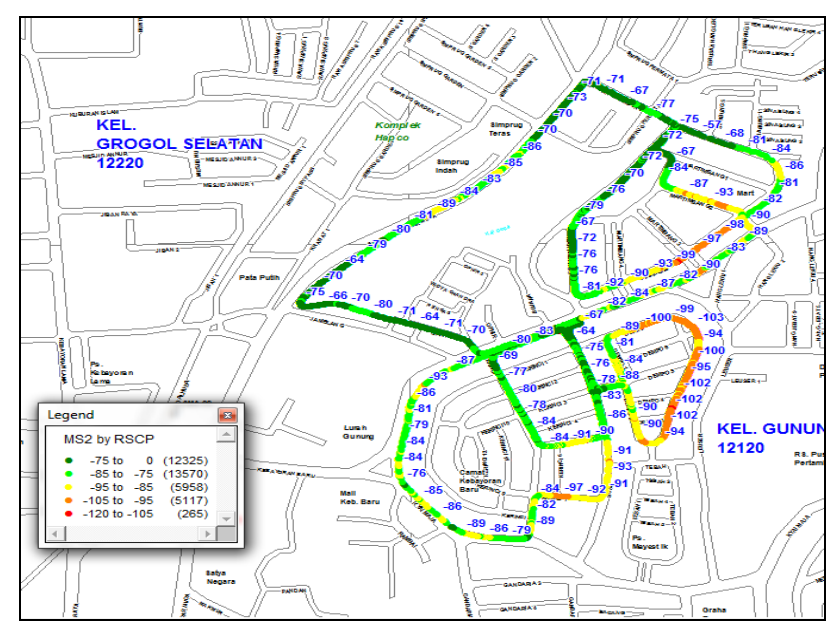

\begin{tabular}{lll}
\hline Range & Count & Persentase (\%) \\
\hline-75 to 0 & 12325 & $33,10 \%$ \\
-85 to -75 & 13570 & $36,44 \%$ \\
-95 to -85 & 5958 & $16,00 \%$ \\
-105 to -95 & 5117 & $13,74 \%$ \\
-120 to -105 & 265 & $0,71 \%$ \\
\hline
\end{tabular}

GAMBAR 10. Perolehan kuat sinyal pada mobile station tilt $2^{\circ}$ dengan penggabungan electrical dan mecanical tilt.

Perolehan Ec/No Tilt $2^{\circ}$ dengan penggabungan electrical dan mecanical tilt ditunjukkan oleh Gambar dibawah ;

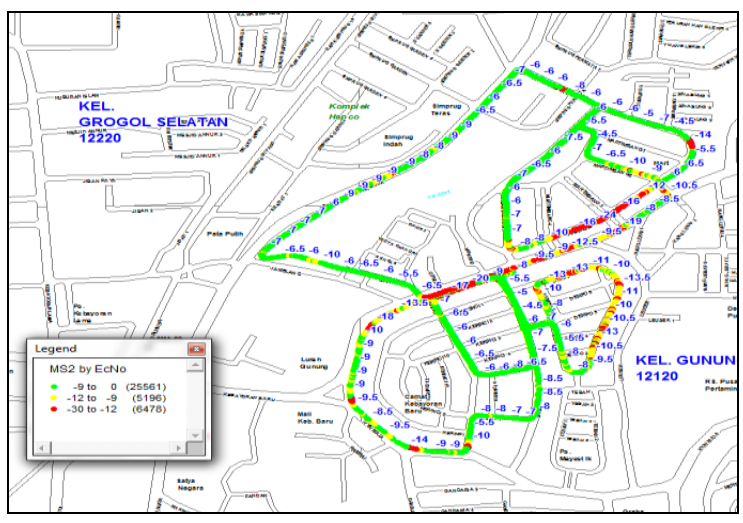

\begin{tabular}{lll}
\hline Range & Count & Persentase (\%) \\
\hline-9 to 0 & 25561 & $68,65 \%$ \\
-12 to -9 & 5196 & $13,95 \%$ \\
-30 to 12 & 6478 & $17,40 \%$ \\
\hline
\end{tabular}

GAMBAR 11. EcNo pada mobile station pada tilt $2^{\circ}$ dengan penggabungan electrical dan mecanical tilt.

Nilai rata-rata penerimaan sinyal dan Ec/No untuk setiap perubahan tilting yang dilakukan ditunjukkan oleh Tabel dibawah ini ;

TABEL 1. Nilai rata-rata penerimaan sinyal dan Ec/No

\begin{tabular}{|c|c|c|c|c|}
\hline Parameter & Tilt $0^{\circ}$ & Electrical $2^{\circ}$ & Mecanical $2^{\circ}$ & ${\text { Electrical } 2^{\circ}+\text { Mecanical } 2^{\circ}}^{\circ}$ \\
\hline Kuat Sinyal $(\mathrm{dbm})$ & -96 & -76 & -90 & -80 \\
\hline Ec/No & 18.2 & -8 & $-24,5$ & -6.5 \\
\hline
\end{tabular}

Dari data yang diperoleh dapat disimpulkan bahwa tilting secara electrical memberikan sebaran daya yang lebih baik dibandingkan dengan mechanical tilt. Apabila tilting tidak dilakukan maka sebaran daya akan menyebar sehingga daya terima pada area yang tercover relatif rendah.

\section{Pengujian Titik Soft Handover}

Pengujian titik soft handover diambil dari posisi active call dimana voice call sedang berlangsung. Titik ditetapkan ketika kedua mobile station telah beralih tanganan pada satu active set pada scrambling code dari site tetangga (Neighbour site). Pergerakan dimulai dari BTS yang diamati (di tilting) menuju BTS neighbor nya pada antena sector yang mengcover soft handover dari BTS uji. Gambar 12 menunjukkan pengukuran jarak dari peta ketika terjadi soft handover dari BTS uji ke BTS Neighbour. 


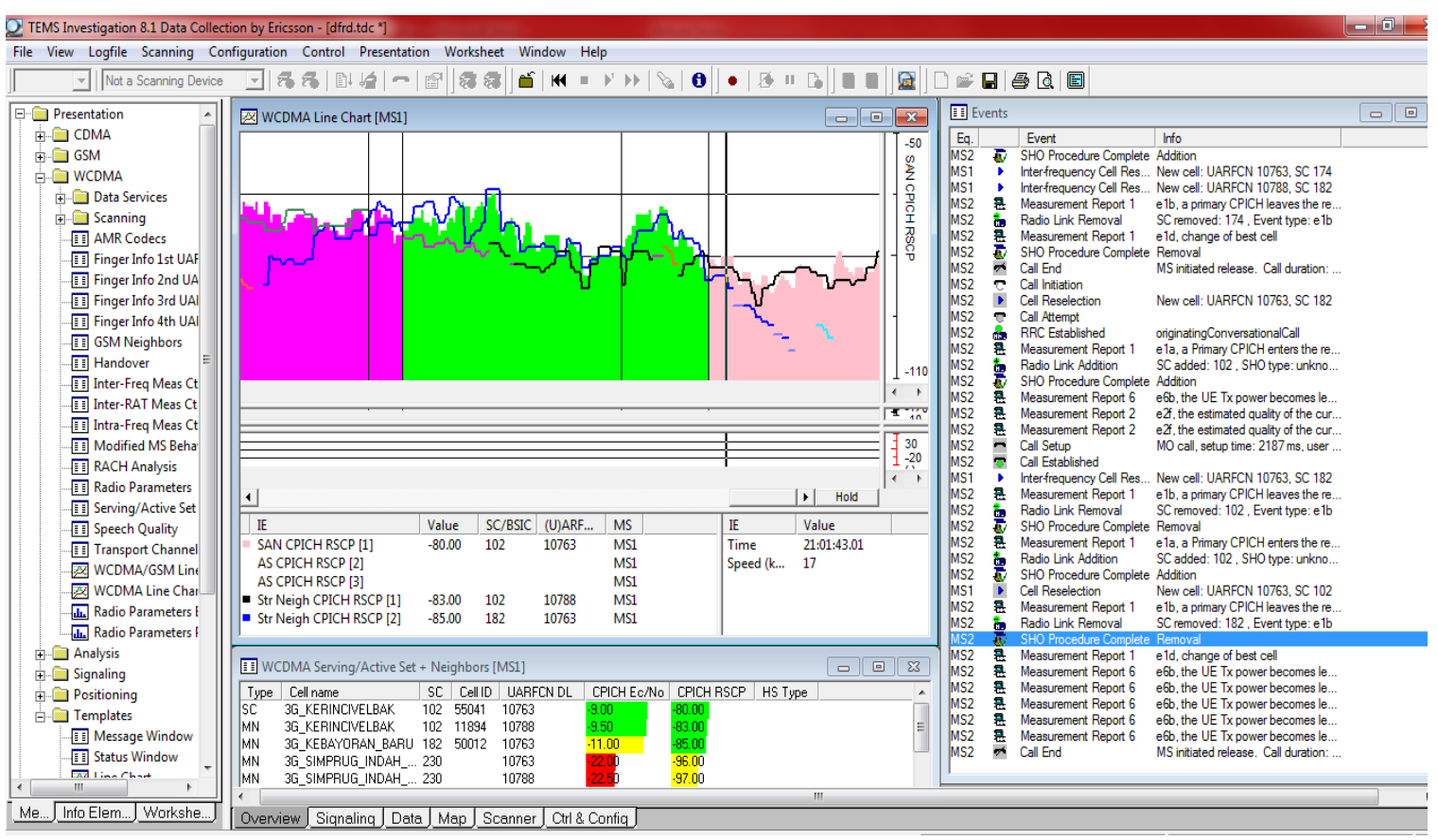

GAMBAR 12. Pegukuran jarak soft handover.

Data hasil pengujian jarak dimana soft handover terjadi ditunjukkan pada tabel 2.

TABEL 2. Jarak Terjadinya Soft Handover

\begin{tabular}{|c|c|c|c|c|}
\hline Parameter & Tilt $0^{\circ}$ & Electrical $2^{\circ}$ & Mechanical $2^{\circ}$ & Electrical $2^{\circ}+$ Mecanical $2^{\circ}$ \\
\hline Titik Soft Handover (m) & 547,1 meter & 579.3 meter & 514.9 meter & 547,1 meter \\
\hline
\end{tabular}

Dari hasil pengujian terlihat bahwa tilting menentukan jarak soft handover. Tilting secara electric terlihat lebih mendekati perhitungan jarak dibandingkan tilting secara mechanical. Dimana telah dihitung bahwa tilting $2^{\circ}$ akan memberikan jarak pancaran beam sebesar 579.3 meter.

\section{Call setup sucses rate (CSSR) voice dan video call}

Pengujian voice, video dan transfer data dilakukan untuk melihat efek dari tilting terhadap layanan-layanan yang dilakukan oleh BTS. Call setup sucses rate (CSSR) adalah salah satu indikasi kinerja dari suatu site. Pada proses call setup ditempuh dalam beberapa tahapan. Dimulai dari pengiriman RRC request hingga komunikasi dapat berlangsung. Adakalanya dibutuhkan beberapa kali RRC Request untuk mendapatkan respon sebelum terjadi pembangunan koneksi. Data diperoleh dari layer 3 Message dari software TEMS yang menunjukkan proses call setup tersebut. Standarisasi CSSR pada provider XL Axiata dirumuskan oleh :

CSSR $=100 \%$ * (\# "RRC Connection Setup Complete" / \# "RRC Connection Request”) * (\# "Alerting" / \# "Setup")

Tabel 3 dibawah ini menunjukkan statistik cal setup pada voice dan video call untuk setiap perubahan tilting yang dilakukan.

TABEL 3. Statistik voice call.

\begin{tabular}{|l|l|c|c|c|}
\hline \multicolumn{1}{|c|}{ Statistics } & \multicolumn{1}{|c|}{ Tilt 0 $^{\circ}$} & Electrical 2 & Mecanical 2 & $\begin{array}{c}\text { Electrical + } \\
\text { Mecanical }^{\left(2^{\circ}\right.}\end{array}$ \\
\hline RRC Connection Request (MS1) & 5 & 5 & 5 & 5 \\
\hline RRC Connection Setup Complete (MS1) & 5 & 5 & 5 & 5 \\
\hline Total Call Setup (MS1) & 5 & 5 & 5 & 5 \\
\hline Call Setup Success (MS1) & 5 & 5 & 5 & 5 \\
\hline Call Setup Success Rate (MS1) & $100 \%$ & $100 \%$ & $100 \%$ & 5 \\
\hline RRC Connection Request (MS2) & 5 & 5 & 5 & 5 \\
\hline
\end{tabular}




\begin{tabular}{|l|l|l|l|l|}
\hline RRC Connection Setup Complete (MS2) & 5 & 5 & 5 & 5 \\
\hline Total Call Setup (MS2) & 5 & 5 & 5 & 5 \\
\hline Call Setup Success (MS2) & 5 & 5 & 5 & 5 \\
\hline Call Setup Success Rate (MS2) & $100 \%$ & $100 \%$ & $100 \%$ & $100 \%$ \\
\hline
\end{tabular}

Dari Tabel diatas terlihat bahwa pada komunikasi voice baik pada tilting $0^{0}$ maupun pada electrical dan mechanical komunikasi berlangsung baik. Tidak terjadi kegagalan apapun baik dari sisi protokol yang dikirim atupun kejatuhan panggilan ketika komunkasi tengah berlangsung.

TABEL 4. Statistik video call.

\begin{tabular}{|l|c|c|c|c|}
\hline \multicolumn{1}{|c|}{ Statistics } & Tilt 0 & Electrical 2 & Mecanical 2 $^{\circ}$ & $\begin{array}{c}\text { Electrical + } \\
\text { Mecanical }\left(\mathbf{2}^{\circ}\right)\end{array}$ \\
\hline RRC Connection Request (MS1) & 6 & 5 & 6 & 5 \\
\hline RRC Connection Setup Complete (MS1) & 5 & 5 & 5 & 5 \\
\hline Total Call Setup (MS1) & 5 & 5 & 5 & 5 \\
\hline Call Setup Success (MS1) & 5 & 5 & 5 & 5 \\
\hline Call Setup Success Rate (MS1) & $83.33 \%$ & $100 \%$ & $100 \%$ & 5 \\
\hline RRC Connection Request (MS2) & 6 & 5 & 6 & 5 \\
\hline RRC Connection Setup Complete (MS2) & 5 & 5 & 5 & 5 \\
\hline Total Call Setup (MS2) & 5 & 5 & 5 & 5 \\
\hline Call Setup Success (MS2) & 4 & 5 & 5 & $100 \%$ \\
\hline Call Setup Success Rate (MS2) & $66.64 \%$ & $100 \%$ & $83.33 \%$ & \\
\hline
\end{tabular}

Dari tabel 4 hasil pengujian terlihat bahwa terjadi satu kali kegagalan panggilan layanan video call pada tilting $0^{0}$ dan pengulangan RRC Request pada tilting $0^{0}$ dan tilting mechanical $2^{0}$. Sedangkan pada tilting secara electrical maupun pada penggabungan electrical dan mechanical komunikasi berlangsung baik.

\section{KESIMPULAN}

Dari hasil analisis yang telah diperoleh maka dapat ditarik kesimpulan bahwa tilting memberikan pengaruh yang sinifikan terhadap cakupan dari suatu BTS. Dari hasil yang di peroleh dari tilting $0^{\circ}$ didapatkan hasil $96 \mathrm{dBm}$, Tilting secara electrical $2^{\circ}$ didapatkan hasil sebesar $-76 \mathrm{dBm}$, tilting secara mechanical $2^{\circ}$ didapatkan hasil sebesar $-90 \mathrm{dBm}$ dan gabungan Tilting secara electrical dan mechanical $2^{\circ}$ didapatkan hasil $-80 \mathrm{dBm}$, tilting secara electrical memberikan perolehan sinyal yang lebih baik di bandingkan tilting secara mechanical, Pada tilting secara electrical didapatkan rata-rata perolehan sinyal yang lebih baik daripada mechanical tilting. Perubahan tilting mengakibatkan perubahan dari titik handover dari suatu BTS ke BTS neighbour. Akurasi yang lebih baik di dapatkan dengan melakukan tilting secara electrical dengan akurasi jarak $579.3 \mathrm{~m}$ daripada secara mechanical dengan akurasi jarak 514.9 $\mathrm{m}$. Dari hasil uji layanan terlihat bahwa perubahan tilting sangat berdampak pada hasil statistik voice call dan video call terlihat pada uji voice call tidak terjadi kegagalan fungsi, tetapi pada uji vidoe call terjadi satu kali kegagalan panggilan layanan video call pada tilting 0 dan pengulangan RRC Request pada tilting 0 dan tilting mechanical 2. Sedangkan pada tilting secara electrical maupun pada penggabungan electrical dan mechanical komunikasi berlangsung baik.

\section{DAFTAR PUSTAKA}

[1] Utomo, Pramudi. 2008. Teknik Telekomunikasi Jilid 1. Jakarta, Hal 127 - 137

[2] Wowok. 2008. Antena Wireless Untuk Rakyat. Penerbit Andi: Yogyakarta.

[3] Balanis, Constantine A. 2005. "Antena Theory - Analysis and Design". Third Edition. John Wiley \& Sons Inc: New Jersey.

[4] Angga Timothy, Karakteristik Antena, http://www.ittelkom.ac.id/library/index.karakteristik antena. 
[5] Rahman, Link Budget VSAT Point-To-Point, http://www.geocities.com/adoel5/BAB3.htm

[6] http://opensource.telkomspeedy.com/wiki/index.php/Antenna_patch_panel

[7] http://anantoep.wordpress.com/2009/12/16/sekilas-tentang-sistem komunikasi-seluler/

[8] Andi Hasad, komunikasi Selular GSM, http://andihasad.wordpress.com/2010/04/26/ komunikasi-selular-gsm/

[9] Frengki, Sistem komunikasi bergerak GSM, http://pemrogramanbascom.blogspot.com/2010/09/sistemkomunikasi-bergerak-gsm.html

[10] Hariman Setiawan, SISTEM KOMUNIKASI SELULER CDMA 2000 1X http://yudhaputera.blogspot.com/2010/10/system-telekomunikasi.html

[11] S Sulistyaningsih - 2010, Optimasi BTS Untuk Peningkatan Kualitas Jaringan CDMA 2000 http://jurnal.informatika.lipi.go.id/index.php/inkom/article/view/15/15 